\title{
ENGLISH SUBJECT ON ENGLISH FOR SPECIFIC PURPOSES (ESP) IN VOCATIONAL SCHOOLS
}

\author{
Fadlia, Evi Zulida, Surya Asra, Rahmiati, Allif Syahputra Bania \\ Universitas Samudra, Langsa, Aceh, Indonesia \\ E-mail: fadlia@unsam.ac.id
}

Received: 11 October 2020

Accepted: 08 December 2020

\begin{abstract}
This study aimed to analyze the English subject in two vocational schools in Kota Langsa based on English for Specific Purposes (ESP) approach and how it was implemented in the classroom. This study applied a descriptive qualitative method. The two vocational schools involved in the research are Hotel Hospitality Management and Maritime Fishing Vessel Engineering. The data were gained from the teachers and students by conducting observation, interview, Focus Group Discusssion (FGD), and document analysis of syllabus and teaching materials. The data were analyzed by comparing the real condition of teaching-learning process and the ideal condition based on ESP approach. The finding showed that the two schools used General English (GE) frequently rather than ESP on English subject. Despite the common use of GE in these two schools, they had the option to adjust their English subject into ESP standard. One school had the ESP subject called English for Maritime and another school chose Mandarin subject as the option. As a result, the school only had GE for English subject. Thus, the English subject was taught and designed as English for General Purposes rather than English for Specific Purposes.
\end{abstract}

Keywords: English subject, ESP approach, vocational school, general English.

\section{Introduction}

The Indonesian government continues to improve human resource development through Vocational High Schools (Sekolah Menengah Kejuruan [SMK]). One of the efforts from the government in educational sector especial for SMK is by issuing several policies through the Decree of Director General of Elementary and High Schools Number 251/C/KEP/MN/2008 Year 2008 regarding Expertise Spectrum in Vocational Schools. This Director General Decree regulates the Vocational Expertise Spectrum to add the variation of specific major in Indonesian vocational schools (Kementerian Pendidijkan dan Kebudayaan [Kemdikbud], 2008). This policy aims at adding the option for various skills for students in vocational schools.

The government has also organized a Revitalization Program for Vocational High Schools through presidential instruction of the Republic of Indonesia. The President issued Presidential Instruction Number 9 Year 2016 regarding Revitalization of Vocational High Schools to Improve the Quality and Competitiveness of Indonesian Human Resources. This presidential instruction is intended to help the educational institutions, especially SMK to create synergies among related agencies and institutions in accordance with their respective duties and functions (Sekneg, 2016). Through this revitalization program, the government 
issues the Guidelines for the Implementation Strategy for Vocational Revitalization through the Bilingual Learning Ecosystem (Kemdikbud, 2017).

Unfortunately, these programs are still only in the form of pilot projects in several vocational schools, especially some vocational schools on the island of Java. A wider implementation is needed for those programs, especially in the Aceh region. Even though the government has paid great attention to the development of the Vocational School Education system, there are still the gaps to be fulfilled. One of these gaps is the syllabus of English subject in SMK. When the syllabus of English at SMK is reviewed, the learning competencies that must be achieved are based on General English view. The syllabus for English subject in SMK (vocational school) is the syllabus that is generally used in General Senior High Schools. In fact, the syllabus of English subjects in SMK needs to be adjusted to the competency of expertise that is specific to each study program.

Therefore, this study aims at determining the extent to which the syllabus of English subjects in vocational schools (SMK) is in accordance with the principles of the English for Specific Purpose (ESP) and how it is implemented in the classroom.

\section{Literature Review}

English for Specific Purposes (ESP) is an approach in which learning English carried out based on the needs of students to achieve specific learning goals, or based on expertise. The examples of ESP approach are English for banking, English for economics and business, English for engineering, and English for tourism.

According to Wright (1992: 3), ESP is a certain specific learning from human activities in language learning. In other words, ESP is a way to teach/ learn English for specific subjects or skills that contain specific vocational goals to achieve certain educational goals (Wright, 1992, p.3). The ESP phenomenon will be easily found in a specific skill of student competency areas, especially in vocational schools (SMK) or universities that educate students to achieve specific goals. Vocational High Schools (SMK) aims to prepare students to become skilled workers. SMK is designed to accelerate the government program to improve Indonesian economy and welfare (Schippers \& Patriana, 1994).

The problem that often arises in teaching English at SMK is related to how to provide English subject to meet the needs of students. English for Specific Purposes (ESP) is becoming an important approach to teaching English. When English is used for special purposes or specific skills, the demands of learning English become very specific, no longer learning English for general purposes (English for General Purposes). To prepare for ESPbased learning, a teacher must pay attention to several points: teaching guidelines, a good ESP syllabus, and the selection of teaching materials for the ESP program. All of this preparation must be carried out before learning begins, so that the preparation of tools and materials is carried out properly and allows for the implementation of learning evaluations. This is also carried out to avoid repetition of teaching materials and student boredom.

In terms of designing relevant English language materials for SMK, it seems necessary to assess information on whether English materials are designed based on the English syllabus which mainly considers the needs of students or not. Munby (1988) states that the point of syllabus design requiring more systematic attention is the communication needs of students, especially the relationship between the derivation of the specification syllabus and students' needs. Consequently, this becomes very important when it comes to designing courses in ESP. 
However, recent studies exploring the needs analysis for English Specific Purposes stated that there is lack of systemic approach in conforming the curriculum development to design the ESP program (Poedjiastutie and Oliver, 2017). The pedagogical challenges also found in teacher context (Poedjiastutie, 2017). Poedjiastutie (2017) finds four aspects that becomes the challenge in pedagogical practices, namely communication focus, learnercentered, collaborative teaching and authentic materials. This paper also confirmed that apart from the differences of GE and ESP, GE can be included to support ESP teaching.

The teacher tends to continue to use GE in classrooms, however students need Specific English to achieve specific skills (ESP). This different reality is also descripted by a long theoretical debate to differentiate between GE and ESP. Because of this long debate, Dudley - Evans and St. John (1998: 4-5) divided the characteristics of ESP into two, namely absolute and variable characteristics.

Absolute characteristics consist of three ideas. (1) ESP is defined to achieve the special needs of its students, (2) ESP-based English learning will use the specific topics to be achieved along with the methods and activities of its activities, and (3) ESP will adapt the language features to the specific expertise will be achieved, for example in terms: grammar, lexis, register, study skills, discourse, and genre.

Variable characteristics include five things. (1) ESP will be designed according to the skill discipline to be achieved. (2) ESP will likely have different teaching methodology with General English, according to the specific learning conditions. (3) ESP will likely be designed for adult students, but not closing the possibility for middle school students. (4) ESP is designed for intermediate and advanced students, and (5) ESP students are assumed to have basic knowledge of English.

On another context of ESP, the notion of English Learning should support the learner's reason for learning English has been brought in broader definition by Hutchinson and Waters (1987). This pioneer theory of Hutchinson and Waters (1987) defined the learner needs into categories of target needs based on: necessities, lacks and wants. Those three language features; necessities, lacks and wants, are covered in term of target needs. This target needs are covering more on the importance of language use. While target needs involve; necessities (what for the English will be needed), lacks (what is learner situation) and wants (what learners feel they need from English).

\section{Research Method}

This study uses a descriptive qualitative method which analyzes the phenomena that occur in learning English at SMK. In this study, the data collection process was carried out in two ways. First, document analysis consisting of curriculum structure analysis and syllabus analysis. Second, the analysis of learning conducted by observing English learning implementation in classroom, interviewing teachers, and conducting focus group discussions (FGD) with students. The process of analyzing the data is through three lines of the research process, namely data reduction, data display, and conclusion drawing/ verification.

This research was conducted at SMK Negeri 3 Langsa and SMK Negeri 4 Langsa. These two schools were chosen because they basically have the same curriculum. The study programs at these two schools have Foreign Language Subjects that can be adjusted according to their specific competence. 


\section{Results and Discussion}

\subsection{Results}

\subsubsection{Document Analysis}

The document analysis carried out in this study consisted of two parts, namely: analysis of curriculum structure and syllabus. The curriculum structure has been determined at the ministerial level through ministerial regulations. The syllabus is a derivative of the existing curriculum structure in schools and can be adapted to the conditions required by each school. For example, when adapting the point of Other English subjects in the curriculum structure, SMK 4 Langsa adapts the points of Other Foreign Language subjects into Maritime English subject. Meanwhile, SMK 3 chooses Mandarin subject.

\section{a. Analysis of Curriculum Structure}

Based on the Decree of Minister of Education and Culture of the Republic of Indonesia Number 60 Year 2014 regarding the 2013 SMK/MAK Curriculum states that SMK/MAK must consider the spectrum of vocational intermediate skills (Kemdikbud, 2014). SMK 3 Langsa has four spectrums of expertise/competency skills, namely: Hospitality, Cullinary, Skin and Hair Beauty and Dressmaking. Meanwhile, SMK 4 Langsa has four skill spectrums/ competencies, namely: Marine Fisheries Agribusiness, Computer and Network Engineering, Fishing Vessel Engineering, Motorcycle Engineering and Business.

In accordance with the focus of this research to analyze English subject based on English for Specific Purposes (ESP) in Vocational High Schools, this study selects two majors that have different initiatives, namely the Hospitality study program from SMK 3 Langsa and Fishing Vessel Engineering (TKPI) study program from SMK 4 Langsa. According to the curriculum documents of these two study programs, they have the same structure of curriculum, they both have the English subject. Besides, these two study programs have Other Foreign Language Programs in their curriculum that can be adapted to the needs of skill competencies.

The result of analyzing curriculum structure in TKPI study Program of SMK 4 and Hospitality study program of SMK 3 can be described as follows. All the study subjects in vocational school are divided into 3 main categories, namely National Content, Regional Content, and Vocational Specific Content. On the national content, there are 352 lesson hours (Jam Pelajaran [JP]) for English and Other Foreign Languages. However, the difference lies in the Vocational Specific Content, TKPI Study Program of SMK 4 has Maritime English subject as many as $72 \mathrm{JP}$. Meanwhile, Hospitality study program of SMK 3 in Vocational Specific Content, there are also $72 \mathrm{JP}$ of foreign language elective subjects in which the school choose Mandarin.

TKPI study program of SMK 4 chooses to adapt other Foreign Language subjects in Vocational Specific Content to Maritime English subject, even though only in the first year. In Hospitality Study Program, the option of foreign language elective subjects remains on the preferred foreign language, namely Mandarin. As a result, Hospitality Study Program only has GE subject which is not specific to skill competencies.

In brief, it can be concluded that Fishing Vessel Engineering study program (TKPI) of SMK 4 has a structure of curriculum that has been adjusted to the principles of ESP (English for Specific Purposes) learning, which is seen in English for Maritime subject and it is also supported by General English. Meanwhile, Hospitality Study Program of SMK 3 only has GE subject (General English only) and does not have ESP English subject. 
Reviewing English Subject on English for Specific Purposes (ESP) in Vocational Schools, Fadlia, Evi Zulida, Surya Asra, Rahmiati, Allif Syahputra Bania

\section{b. Syllabus Analysis}

The syllabus is a document for guiding learning material derived from the curriculum structure. TKPI study program of SMK 4 has two English syllabi, namely the syllabus of General English and English Maritime. Meanwhile, Hospitality study program of SMK 3 only has one English syllabus, namely General English syllabus.

Both SMK 4 and SMK 3 have the same syllabus for General English Subject, based on Core Competency (KI) and Basic Competency (KD) in the curriculum document issued by the Ministry of Education and Culture. In the KI and KD, English Lesson is for "All Areas of Expertise". With the competence of all areas of expertise, it can also be translated from the basic competencies of English Subjects which contain: "Composing short and simple oral and written transactional interaction texts involving the act of giving and asking for information related to identity" with an example of learning "introduction, Introducing friends".

The syllabus of English subjects that support skill competency is only owned by SMK 4 which has English for Maritime Subject in TKPI study program. The table below shows the syllabus of English for Maritime subject.

Table 1. Syllabus of Maritime English

\begin{tabular}{|c|c|c|}
\hline \multicolumn{2}{|r|}{ BASIC COMPETENCIES } & BASIC COMPETENCIES \\
\hline & $\begin{array}{l}\text { Understand; identifies and names of the } \\
\text { main parts of a passenger vessel in } \\
\text { speech and writing }\end{array}$ & $\begin{array}{l}4.1 \text { Apply; identifies and names of the main parts } \\
\text { of a passenger vessel in speech and writing }\end{array}$ \\
\hline 3.2 & $\begin{array}{l}\text { Understand; asksfor and gives personal } \\
\text { data }\end{array}$ & 4.2 Apply; ask for and gives personal data \\
\hline 3.3 & $\begin{array}{l}\text { Describes crew roles and routines on } \\
\text { board passenger vessels }\end{array}$ & $\begin{array}{l}\text { 4.3 Apply crew roles and routines on board } \\
\text { passenger vessels }\end{array}$ \\
\hline 3.4 & Describes job responsibilities on board & 4.4 Apply job responsibilities on board \\
\hline 3.5 & $\begin{array}{l}\text { Understand; considers instructions on } \\
\text { board ship }\end{array}$ & 4.5 Apply; considers instructions on board ship \\
\hline 3.6 & $\begin{array}{l}\text { Understand; trainees will role play the } \\
\text { various drills on board ships }\end{array}$ & $\begin{array}{l}\text { 4.6 Apply; trainees will role-play the various drills } \\
\text { on board ship }\end{array}$ \\
\hline 3.7 & $\begin{array}{l}\text { Understand; discusses human behaviour } \\
\text { in emergencies }\end{array}$ & $\begin{array}{l}4.7 \text { Apply; discusses human behaviour in } \\
\text { emergencies }\end{array}$ \\
\hline 3.8 & $\begin{array}{l}\text { Apply; practises the communication } \\
\text { related to crowd and crisis management } \\
\text { in an emergency }\end{array}$ & $\begin{array}{l}\text { 4.8 Demonstrate; practises the communication } \\
\text { related to crowd and crisis management in } \\
\text { an emergency }\end{array}$ \\
\hline
\end{tabular}

From the table 1 above, some basic English language competencies support skill competencies at TKPI. The English teacher in SMK 4 tries to conduct the learning process according to the syllabus. For example, the teacher was carrying out basic competency number 1, namely identifying parts of the ship in English. Other basic competencies already contain skilled competencies and can be included in English for Specific Purposes. For Instance: students can explain routine activities on ships and students understand instructions onboard. The communication unit is also reflected through basic competence in "implementing communication practices in an emergency". Although the basic competency unit aims to support skill competencies, it is still a very simple task. The result of interviews with teachers revealed that there is only syllabus issued from Ministry of Education and Culture without being equipped with complete teaching materials. The challenge for English teachers in teaching English for Maritime subject is that they get difficulties in finding 
learning materials based on the above basic competencies. They can only find teaching materials on the internet and adapt to the basic competencies above.

\subsubsection{The Analysis of English Teaching and Learning Process}

The result of observations in the class and interviews with English teachers shows that teaching and learning process of English Subject in vocational schools is still in the form of General English. The curriculum that was derived from the Ministry of Education and Culture is only in General English. This is reflected in the Core and Basic Competencies of learning English which are still very general.

Although English is widely used in specific skill subjects such as: House keeping subjects and Front Office subjects in SMK 3, there is no specialization in learning English according to specific skill in SMK 3. However, specific English learning has been reflected in several skill subjects in SMK 4. There is an English lesson for Maritime subject under the Specific Skill Subjects (Skilled Competency: Fishing Vessel Engineering).

\section{a. Learning Process in SMK N 4 Langsa}

The data obtained from SMK 4 reveals that there is an English lesson for Maritime subject under the specific group subject (Specific Competency: Fishing Vessel Engineering). The researchers conducted an observation of learning process in SMK 4 Langsa. It was the first meeting on Maritime English learning subject after the new school year started in a new normal condition in pandemic Covid 19 situation. Face-to-face meetings were carried out by following learning protocols of Covid 19 in green areas of pandemic. At this meeting, the English teacher gave material in the form of terms found in ship propulsion installations such as marine gearbox, propeller, stern tube, etc.

From the observation and interview, the teacher introduced the parts of the vessel in the aim to provide knowledge to students about shipping terminologies in English. This is also intended to make it easier for students to practice fishing vessel engineering subjects. From this observation, it can be concluded that maritime English learning content has at least led to achieving skills competency learning outcomes.

The teachers also stated that most students have "low English Ability" in learning English as the weaknesses (Lacks) of students in learning Maritime English. Almost $70 \%$ of students in the class do not have a basic structure of English. This is due to the background of students who come from low economic background and come from coastal areas. English has become a very foreign language for most of them. The teacher revealed in the interview that "it is difficult for them to speak Indonesian because the first language used is local languages (mostly Acehnese)" and the second language is Bahasa Indonesia.

From Focus Group Discussion (FGD) with the students, the result was found that students expressed their need in more specific term in shipping engineering. One student even said that "it was difficult for us to not know the term ship during shipping engineering practical lessons". They said they wanted to be able to speak English fluently when they would later work in the shipping sector. They also expressed their agreement that English for Maritime was taught using ship pictures as described by their teacher. The question framework in the FGD is prepared based on Hutchinson and Water (1987) on Necessities, Lacks and wants English for Maritime.

Regarding the learning activity, students stated that they chose to study in a group, so that they could help each other in doing assignments. They also admitted that eventhough they have a low level of English; they understand what is being instructed when the teacher 
gives the term in English in the subject of vessel engineering laboratory. Interestingly, when students were asked about their future needs for English, $60 \%$ of them said that they need English for future jobs in shipping.

ESP principles prioritize student centered learning, teachers have shown efforts to activate students, even though learning is not fully student centered. This is obtained from the results of classroom observations when the teacher divided students into groups. This group was tasked with finding pictures of the ship's parts. Each group presented their search results in the form of a picture of the ship with its specific terms in English.

\section{b. Teaching and Learning Activity in SMK N 3 Langsa}

The analysis of curriculum structure and syllabus shows that learning English in SMK 3 Langsa is only General English (GE). However, from interviews with teachesr and observations, the English teachers try to specify learning according to the competence of expertise in several topics. For example, in the English course syllabus on answering the phone, the teachers try to deepen this subject by explaining in detail when teaching answering the phone material in Hospitality study program.

The challenge in conducting English Learning based on the specific competences both in SMK 3 and SMK 4 Langsa is that the National Examination material for SMK remains general (General English). Consequently, the teacher set aside specific goals according to the skilled competence in carrying out English learning. From the document analysis on the National examination questions, it was found that only general English skills were tested. Therefore, teachers focused on teaching students on general English to achieve high scores in National Examination.

English textbooks are written based on 2013 SMK curriculum structure, therefore all English textbooks are written for general English only. The books used in General English lessons for SMK are published by the Ministry of Education and Culture, 2016 Revised Edition, written by Utami Widiati, Zuliati Rohmah and Furaidah with publishing supervisors: Center for Curriculum and Books, Balitbang, Kemdikbud. This book is designed for all skills in SMK based on the 2013 curriculum. This book is written and used in SMK with the aim of helping students achieve the four core competencies (KI) in 2013. Book presentation is referred to as a text-based language learning approach, both oral and written, using English as a means of communication (Widiati, et. al, 2016).

SMK 3 Langsa does only have General English subjects, without any subjects that support skills competencies based on English for Specific Purposes. However, there are many English terms that are introduced and explored, such as: terms in Front Office subject, House keeping and Food and Beverage skilled subjects in the skilled subject in Hospitality study program. The subjects contained in the Skills Competency itself are named in English Naming, as exemplified above, namely: Front Office, House Keeping, Food and Beverage and Laundry subjects. The terms are also introduced a lot in English, for example: the use of Function Room, Public Area, Dining Room, and similar terms in English. In fact, in Front Office lessons, the skill of answering the phone is specifically discussed in English along with the steps and procedures (full in English). Reservation skills are also discussed in English, about how to handle reservations in English. 


\subsection{Discussion}

A long debate about how to differentiate English for Specific Purposes (ESP) and General English (GE) had became a notion in teaching-learning English. The characteristics of ESP which is proposed by Dudley-Evans and St. John (1998, p.4-5) is still used until this current time. The absolute characteristics of ESP Dudley-Evans and St. John (1998) are: ESP is defined to meet the specific needs of the Learners, ESP makes use of the underlying methodology and activities of the discipline it serves, ESP is centered on the language appropriate to these activities in terms of grammar, lexis, register, study skills, discourse, and genre. On the context of SMK 4 and SMK 3, whether the English Subject has been aligned with the specific needs of learner has been studied or not. SMK 4 choses to align one of their options in vocational school curriculum "other foreign language into English for Maritime". Even though the implementation is not fully executed as a complete teaching and learning process (presentation, practice, and production). Maritime English Subject has been indicated that the school provide the English subject which supported the needs of the student in their major, the Technique of Fishery Vessel (Teknika Kapal Penangkap Ikan).

The notion of "English Learning should support the learner's reason of learning English" has been brought in broader definition by Hutchinson and Waters (1987). This pioneer theory of Hutchinson and Waters (1987) defined the learner's needs into categories of target needs based on: necessities, lacks and wants as the basic justification of students' focus group discussion in this research. Interestingly, what has become the teacher concerned about lack of teaching learning process, that student has the lower English background because the student feel very foreign into English, is not linear about what students brought in FGD. When student asked, whether they realize about the needs of English, students said they need English for their future in working in international vessel. This aim might be contrary with the reality of 'English is very far away from student's daily reality" stated by teacher. Students with low economic background, which is identified as one of the causes why they have a lower basic English, become one of the main topics in teacher's interview. As a benefit, it can be viewed that aside from the reality of students' background, the students themselves have strong motivation to learn English.

The student centeredness also becomes the proposal of teaching method in ESP by Hutchinson and Waters (1987). It must be aligned in the notion of "teaching English should be based on the learner's needs." On the context of research in SMK 4, teacher has made efforts to treat student as the center of the learning. In English for Maritime subject, the teacher draws the picture of a vessel on the white board and invites the students to work in groups to complete other parts of the vessel picture in English. This kind of learning activities is only recognized as the surface level of student centered, at least the teacher has made an effort to invite the students to participate in his class. The teacher centeredness has been embedded deeply in class instruction and part of Indonesian culture (Bjork, 2005) can be the reference of why the fully student centeredness cannot be executed holistically.

Ten years of Hutchinson and Waters (1987) coming with the notion of ESP, Anthony (1997) proposes that: ironically, while many General English teachers can be described as using an ESP approach, basing their syllabi on a learner needs analysis and their own specialist knowledge of using English for real communication (p.2). The notion of the teacher uses their own specialist knowledge to use English in real communication (Anthony, 1997) has been shown in the effort of the general English teacher did some additional explanation on the general English which beneficial for the major. In the observation of SMK 4, English teacher has more explanation on "answering the phone" material for Hospitality 
study program. She has the initiative to do some more deeper explanations, more examples and more communication in this material. It could be the implementation of what Anthony (1997) proposes in the notion of "teacher use their own specialist knowledge to use English in real communication".

\section{Conclusion}

The current study has provided the answer for the research question. Firstly, the syllabus from the Ministry of Education for the English Subject in vocational school is General English. Vocational schools do have the opportunity to adjust the syllabus to ESP. In SMK curriculum there is one point of "other foreign languages" in the category specific competence subject which can be adjusted to the needs of the students. One vocational school prefers to adjust the "other foreign languages" into English for Maritime, while another school prefers Mandarin language on that point and only has General English in English subject.

The result of teaching learning process both in English for Maritime and General English has led to various results. In English for Maritime, teacher already has the effort to provide the material specific for student's needs. Even though the teaching process is not delivered with full cycle of presentation, practice and production, teacher has made the effort to let the student contribute to the learning process. The Teacher has also expressed the importance of building the student centeredness in English for Maritime class, even though it was not executed on the whole layer of students. In General English class, the teacher has made the effort to have more explanation, more building understanding on the general material which is assumed to be suitable for their vocational purposes, for example in the material of answering the phone for hospitality class. However, the teacher tends to run the class for national examination, which focuses on general English.

From the finding, there is a need for the government to review the national curriculum of vocational school in Indonesia to create a more specific purposes on the English Subject based on each vocational skill. The guidance system also needs to prepare the vocational school to give them opportunity to adapt their English Subject to vocational purposes. It should be established, either it can be the system, training of the teacher and adjustment of syllabus document. Furthermore, the suitable training of the vocational school English teachers can be planned to maintain the English teachers' proficiency and to give the framework of the teachers to adjust themselves from General English to English for Specific Purposes.

To understand the deeper analysis on Vocational High School English syllabus in Indonesia, further research should be conducted in vocational schools. Since this research was conducted only in two schools, the generalization is difficult to be described. However, this study has provided a point view how the English Subject is designed in vocational schools.

\section{References}

Anthony, L. (1997). ESP: What does it mean? Why is it different? On CUE. Retrieved from http://www.antlab.sci.waseda.ac.jp/abstracts/ESParticle.html

Bjork, C. (2005). Indonesia education: Teachers, schools, and central bureaucracy. London: Routledge.

Dudley-Evans, T. \& St John, M. J. (1998). Developments in English for specific purposes. Cambridge: Cambridge University Press. 
Hutchinson T. \& Waters, A. (1987). English for specific purposes: A learning-centered approach. Cambridge: Cambridge University. doi:10.1017/CBO9780511733031

Kementerian Pendidikan dan Kebudayaan [Kemdikbud]. (2008). Keputusan Direktur Jendral Manajemen Pendidikan Dasar dan Menengah. Jakarta: Departemen Pendidikan Nasional. Retrieved from http://smk.kemdikbud.go.id/konten/473/spektrumkeahlian-pendidikan-menengah-kejuruan-

Kemdikbud. (2017). Strategi implementasi revitalisasi SMK melalui bilingual learning ecosystem untuk Sekolah Menengah Kejuruan. Jakarta: Direktorat Pembinaan Sekolah Menengah Kejuruan. Retrieved from http://repositori.kemdikbud.go.id/5265/

Kemdikbud. (2014). Peraturan Menteri Pendidikan dan Kebudayaan Republik Indonesia. Jakarta: Biro Hukum dan Organisasi Kemdikbud. Retrieved from https://jdih.kemdikbud.go.id/arsip/Permendikbud_Tahun2014_Nomor60.pdf

Munby, J. (1988). A syllabus design. Oxford: Oxford University Press.

Poedjiastutie \& Oliver. (2017). English learning needs of ESP learners: Exploring stakeholder perceptions at an Indonesian University. TEFLIN Journal, 28(1). https://journal.teflin.org/index.php/journal/article/view/421.

Poedjiastutie, D. (2017). The pedagogical challenges of English for specific purposes (ESP) teaching at the University of Muhammadiyah Malang, Indonesia, Educational Research Reviews. 12 (6), 338-349. doi:10.5897/ERR2016.3125

Sekneg. (2016). Intruksi Presiden Republik Indonesia. Jakarta: Sekretaris Kabinet RI. Retrieved from http://kemdikbud.go.id > files > download

Schippers, U. \& Patriana, D. M. (1994). Pendidikan kejuruan di Indonesia. Bandung: Penerbit Angkasa.

Widiati, U., Rohmah, Z., \& Furaidah. (2016). Bahasa Inggris Kelas X. Jakarta: Kementrian Pendidikan dan Kebudayaan.

Wright, C. (1992). The benefits of ESP. Cambridge: Cambridge Language Consultants. 